\title{
COMMENTS
}

\section{Bank Insolvency and Depositor Setoff}

Since 1933, when the Federal Deposit Insurance Corporation (FDIC) was created ${ }^{1}$ to help restore public confidence in banks following the widespread failures of the Depression, ${ }^{2}$ bank insolvencies have been relatively rare. ${ }^{3}$ As a consequence, courts and legislatures have had little occasion to re-examine the rules and practices governing the settlement of claims against a failed bank. The dramatic collapse, however, of the Penn Square Bank, N.A., of Oklahoma City on July 5, 1982, ${ }^{4}$ as well as the surprisingly large number of bank failures since $1981,{ }^{5}$ has refocused the attention of

1 The Federal Deposit Insurance Corporation was originally created by the Banking Act of 1933, Pub. L. No. 73-66, \& 8, 48 Stat. 162, 168, as an amendment to the Federal Reserve Act, Pub. L. No. 63-43, § 1, 38 Stat. 251, 251 (1913) (codified as amended at 12 U.S.C. $\S \S$ 221-522 (1982)). In 1950, the provisions covering the Federal Deposit Insurance Corporation were amended and withdrawn from the Federal Reserve Act by the Federal Deposit Insurance Act, Pub. L. No. 81-97, § 2(1), 64 Stat. 873, 873 (1950). The current provisions covering the corporation are codified at 12 U.S.C. $\$ \S 1811-1832$ (1982).

2 See P. Trescott, Financing American Enterprise: The Story of Commercial BankING 193-217 (1963), which argues that bank failures of the Depression were due to "overbuilding, overspeculation on credit, [and] undue vulnerability by the banks" in the 1920's, id. at 205, and that the creation of the FDIC helped to provide not only a pool of funds but also rigorous policies, which raised the standards even of nonmember banks, $i d$. at 207-08. See also J. Sinkey, Problem and Falled Institutions in the Commercial Banking IndusTRY 13-14 (Contemporary Studies in Economic and Financial Analysis Vol. 4, 1979) (noting that until 1929 there was little concern about the soundness of the banking system as a whole, but that Congress quickly recognized that a system-wide approach was necessary to restore public confidence and so passed the Banking Act of 1933).

3 During the eight years following the creation of the FDIC bank failures were common, reaching a high of 75 in 1937. See Federal Deposit Insurance Corporation, 1981 Annual REPORT 72-73 table 124 (statistics for failed banks requiring disbursement by the FDIC, 1934-1981). Between 1943 and 1974, fewer that ten banks failed in any given year and in many years, fewer than five. Id. The economic circumstances of the mid-1970's may account in part for the failure of thirteen banks in 1975 and sixteen in 1976. Id. In each of the years 1979,1980 , and 1981, ten banks failed. Id.

- The Penn Square failure was widely covered in both the popular and the financial press. See, e.g., Am. Banker, July 7, 1982, at 1, col. 4; id. at 2, col. 2; Wall St. J., July 6, 1982, at 13, col. 4. Comments have also appeared in academic journals. See, e.g., Essay, Aftermath of Penn Square Bank: Protecting Loan Participants from Setoff, 18 TuLSA L.J. 261 (1982).

- A total of 42 FDIC insured banks failed in 1982, including Penn Square. N.Y. Times, 
legislators, the banking community, and the public on the adequacy of the present regulatory system and on the question of how best to resolve the various disputes that may follow a bank failure. ${ }^{6}$

Among the first questions litigated in the aftermath of the Penn Square failure was the scope of a depositor's right to set off the amount of his deposit in the failed bank against his own outstanding obligation to the bank. ${ }^{7}$ During the six years prior to its failure, Penn Square had increased its assets from $\$ 30$ million to $\$ 400$ million by lending aggressively to independent oil and gas producers operating in Oklahoma. ${ }^{8}$ Beyond developing energy-related credits for its own portfolio, Penn Square acted as a loan broker for various major banks, including Chase Manhattan in New York and Continental Illinois in Chicago. ${ }^{8}$ Penn Square made loans to borrowers in Oklahoma and then sold participations ${ }^{10}$ - sometimes for $100 \%$ of the amount of the loan ${ }^{11}$ - to other

June 17, 1983, at D1, col. 3: Forty-eight banks failed in 1983, and FDIC officials foresaw no immediate drop-off in the failure rate during 1984. Am. Banker, Jan. 6, 1984, at 1, col. 2.

- See, e.g., Bettner, Do You Know Who Is Borrowing Your Money?, Wall St. J., Aug. 9, 1982, at 34, col. 1 (noting that Penn Square failure raises questions about the disclosure and investment practices of the nation's banks); Back to Square One, Wall St. J., July 29, 1982, at 18, col. 1 (editorial concerning the Penn Square collapse and the need for regulatory reform); McGinley, FDIC Chief Gets Generally Good Reviews, But Upsets Some Banking, Savings Officials, Wall St. J., July 26, 1982, at 19, col. 4 (discussing controversy in the banking community over the FDIC handling of the Penn Square failure).

Even prior to the Penn Square failure, Congress was planning legislation to enhance the ability of the FDIC to assist troubled banks. The Garn-St. Germain Depository Institutions Act of 1982, Pub. L. No. 97-320, tit. I-II, $\S \S 111-18,203-05$, 96 Stat. 1469, 1469-79, 1492-99 (codified in scattered sections of 12 U.S.C. (1982)), gave the Corporation expanded powers to provide direct or merger-related assistance to both failed and failing banks, and authority to increase or maintain the capital of certain qualified institutions. Among the stated aims of the Act was a wish to "provide flexibility to the Federal Deposit Insurance Corporation, the Federal Savings and Loan Insurance Corporation, and the Federal supervisory agencies to deal with financially distressed depository institutions . ..." S. REP. No. 536, 97th Cong., 2d Sess. 1, reprinted in 1982 U.S. Code Cong. \& AD. News 3054, 3055.

7 Chase Manhattan Bank brought suit on July 19, 1982, to enjoin the FDIC from allowing certain Penn Square depositors to set off their deposit balances against their outstanding loans. Chase Manhattan Bank v. FDIC, 554 F. Supp. 251, 253 (W.D. Okla. 1983). For an account of the preliminary stages of Chase's suit, see Wall St. J., July 21, 1982, at 6, col. 2 ; id., July 19,1982 , at 6 , col. 3 .

- See Am. Banker, Apr. 26, 1982, at 1, col. 1 (discussing Penn Square's business practices).

- Id.

${ }^{10}$ A loan participation is an interest in a loan sold by the original lender, the "lead," to another institution, the "participant." A lead sells participations in a loan to distribute the risk of the loan or, if the lead is small, in order not to exceed its legal lending limit. See Armstrong, The Developing Law of Participation Agreements, 23 Bus. LAw. 689 (1968); Hutchins, What Exactly is a Loan Participation?, 9 RuT.-CAM. L.J. 447, 448-49 (1978); Stahl, Loan Participations: Lead Insolvency and Participants' Rights (pt. 1), 94 Banking L.J. 882, 882-884 (1977). 
banks. When Penn Square failed, approximately $\$ 2$ billion in participations were outstanding. ${ }^{12}$ These participations, in many respects typical of those used throughout the banking industry, ${ }^{13}$ provided that the obligation of the borrower ran to the "lead bank,"14 which in turn would distribute the borrower's payments on the loan pro rata to the participants. ${ }^{15}$ Upon the failure of Penn Square, many of the original borrowers under these participated loans who were also depositors in the bank sought to set off their account balances against their outstanding obligations. ${ }^{16} \mathrm{~A}$ number

A participant is motivated to participate in a loan by the prospect of a significant return. Loan participations have also been popular because they bypass much of the legal work involved in the transfer of whole loans. Hutchins, supra, at 447. Participants in the Penn Square energy-related loans saw an opportunity for profit: "A gold-rush mentality developed toward energy lending in the 1970's. Oil prices had soared and the industry had been untouched by two general recessions. To Northern bankers, burdened by troubled local industries and competition from foreign banks, '[e]nergy became a vision of gold . . . ." Gigot, Banks Hurt by Penn Square Collapse Were Victims of Oil Slump, Greed, Wall St. J., July 19, 1982, at 17, col. 4 .

For a sample participation certificate and participation agreement, see Armstrong, supra, at 696-700.

11 Affidavit of Edward G. Moran (a vice president of Chase Manhattan Bank) in Brief of Plaintiff, Chase Manhattan Bank, N.A., in Opposition to Defendants Motion to Dismiss or for Summary Judgment at 3, Chase Manhattan Bank v. FDIC, 554 F. Supp. 251 (W.D. Okla. 1983) (on file with The University of Chicago Law Review) [hereinafter cited as Chase Manhattan Brief].

${ }_{12}$ Gigot, supra note 10, at 17, col. 4. For a chart specifying the individual participant banks and the amounts of their respective participations, see Penn Square Bank Failure: Hearings Before the House Comm. on Banking, Finance and Urban Affairs, 97th Cong., 2d Sess. 392 (1982) [hereinafter cited as Penn Square Hearings].

1s In a typical loan participation, "[t]he participants can look only to their lead for satisfaction of claims arising out of the transaction; they are not themselves creditors of the borrower and so cannot assert creditor claims against the borrower." Armstrong, supra note 10, at 693. On occasion participants also enter into side contracts with the borrower giving the participant rights directly against the borrower. Id. at 693-94; see infra notes 168-69 and accompanying text.

14 "The Bank [Penn Square] reserves the sole right to enforce the obligations of the borrower . . . ." Certificate of Participation No. 3156 Between Penn Square Bank, N.A. and Chase Manhattan Bank, N.A. (July 24, 1981) (attached as Exhibit A to Chase Manhattan Brief, supra note 11). The terms of the participation did provide, however, that if a participant's aggregate share in Penn Square's loans to a particular borrower was greater than $50 \%$, Penn Square would take such action to enforce the agreement as the participant requested, provided that the participant indemnified Penn Square against the participant's pro rata share of any expense or liability which Penn Square might incur in so doing. Id. (item 5 of the participation terms).

18 "The Bank [Penn Square] will promptly credit the account of, or remit to, the participant the participant's pro rata share of all payments of principal of or interest on the abovementioned loan ...." Id.

16 The FDIC has revealed neither the precise number of depositors seeking setoff against participated loans nor the amounts involved. A major issue in Chase's dispute with the FDIC involved the receiver's refusal to disclose information about the setoffs. See Memorandum of Law in Support of Plaintiff's Motion for an Order Compelling Discovery at 7-8, 
of the participating banks, faced with the possibility that the obligations upon which their right to repayment ultimately depended would be extinguished, at least in part, brought suit to enjoin the FDIC, as receiver for Penn Square, from permitting the claimed setoffs. ${ }^{17}$

While courts have long acknowledged the availability of the right of setoff against an insolvent bank as an equitable remedy, they have made little effort to delineate the principles underlying their legal conclusions. ${ }^{18}$ This lack of reasoned explication, together with the infrequency with which setoff disputes have arisen until recently, has left banks, depositors, and courts ill-equipped to analyze the setoff rights in complicated circumstances such as those of the Penn Square collapse. This comment suggests that setoff is justified because it enables the FDIC to employ the most efficient methods for handling a failed bank. More importantly, this comment justifies setoff as a means of protecting depositors who have dealt twice with a bank prior to its insolvency, arguing both that it is unfair to ask a depositor who is also a borrower to pay his loan in full while recovering only part of his deposit in post-insolvency collective proceedings, and that it is likely that de-

Chase Manhattan Bank v. FDIC, 554 F. Supp. 251 (W.D. Okla. 1983) (on file with The University of Chicago Law Review); see infra notes 146-62 and accompanying text.

${ }^{17}$ Both Chase Manhattan and Hibernia National Bank of New Orleans filed suit against the FDIC over its setoff policy shortly after Penn Square failed. Wall St. J., July 21, 1982, at 6, col. 2. The FDIC filed an alternative motion to dismiss or for summary judgment against Chase. See Reply Brief of Defendant in Support of its Alternative Motion to Dismiss or for Summary Judgment, Chase Manhattan Bank v. FDIC, 554 F. Supp. 251 (W.D. Okla. 1983) (on file with The University of Chicago Law Review) [hereinafter cited as FDIC Reply Brief]. Northern Trust Co. of Chicago, also a participant in the Penn Square loans, filed an amicus brief in support of Chase's claims on the ground that "the FDIC's future conduct as to participated loans other than those involving Chase may be affected by this Court's ruling with respect to Chase ...." Amicus Brief of Northern Trust Co. at 1-2, Chase Manhat$\tan$ Bank v. FDIC, 554 F. Supp. 251 (W.D. Okla. 1983) [hereinafter cited as Northern Trust Amicus Brief] (on file with The University of Chicago Law Review).

18 See, e.g., Scott v. Armstrong, 146 U.S. 499, 507 (1892) (acknowledging the power of courts in equity to grant setoff); FDIC v. Mademoiselle of Cal., 9 F.2d 660, 663 (9th Cir. 1967) (same); Gray v. School Dist., 67 F.2d 141, 143 (3d Cir. 1933) (same); see also Clark, Set-Off in Cases of Immature Claims in Insolvency and Receivership, 34 HARv. L. REv. 178 (1920) (discussing the development of the theory of equitable setoff from the civil law); Moore \& Sussman, The Current Account and Set-Offs Between an Insolvent Bank and Its Customer, 41 YALE L.J. 1109, 1116 (1932) (an example of legal realist scholarship by Underhill Moore, arguing that "if there are cross obligations arising from a loan or discount or cross obligations resulting from several distinct transactions then the determination ... of the amount which the receiver may collect or ... the customer ... prove require[s] the careful distinction of one type of situation from another, minute analyses of each and precise discrimination in the choice and application of legal rules"). For a survey of the blackletter law on setoff and a compendium of cases, see $5 \mathrm{~A}$ A. MrchIE, ON BANKS AND Banking, ch. 9, §§ 152-163 (rev. perm. ed. 1950 \& Supp. 1982). 
positors as a group would agree ex ante to allow setoff. ${ }^{19}$ The comment concludes by examining the extent of the depositor's setoff right when the insolvent bank has sold a participation interest in his loan to another bank, and suggests that in the absence of a specific contractual provision to the contrary between the depositor-borrower and the participant, the former's setoff right should prevail over the participation interest.

\section{The Statutory Setting}

\section{A. Setoff and Bankruptcy Law}

The right to set off mutual credits in insolvency emerged as a statutory remedy for creditors under English bankruptcy law at the beginning of the eighteenth century. ${ }^{20}$ Prior to these statutes, the common law had required that mutual claims be pursued separately, ${ }^{21}$ though courts of equity had permitted setoff on grounds of unfairness. ${ }^{22}$ The first United States bankruptcy statute, modeled on English law, recognized the right to set off mutual credits ${ }^{23}$ and the remedy has been a feature of every subsequent statute. ${ }^{24}$

18 A failed bank will, of course, have unsecured nondepositor creditors. Their interests have been excluded from the analysis pursued in this comment to simplify the discussion and for the reasons adduced infra notes 136-45 and accompanying text.

${ }^{20} \mathrm{See}$ An Act to Prevent the Committing of Frauds by Bankrupts, 1732, $5 \mathrm{Geo} .2$, ch. $30, \S 28$ ("Where it shall appear to the said commissioners . . . that there hath been mutual credit given by the bankrupt and any other persons or mutual debts between the bankrupt and any other person, at any time before such person became bankrupt, the said commissioners . . . shall state the account between them, and one debt may be set against another, and what shall appear to be due on either side of the balance of such account, and on setting such debts against one another, and no more, shall be claimed or paid on either side respectively."); An Act to Prevent Frauds Frequently Committed by Bankrupts, 1705, 4 Anne ch. 17, § 11 ("that where there shall appear to the commissioners ... that there hath been mutual credits between such person or persons, against whom such commission shall issue forth, and any person who shall be debtor or debtors to such person or persons, and due proof thereof made, and that the accounts are open and unballanced, that it shall be lawful for the commissioners ... to adjust the said account, and to take the balance due in full discharge thereof, and the person debtor to such bankrupt, shall not be compelled or obliged to pay more than shall appear to be due on such balance."). For a history of the setoff doctrine, see Loyd, The Development of Set-Off, 64 U. PA. L. REv. 541, 541-63 (1916) (discussing the history of setoff from Roman Law to the development of the remedy by English Courts of Chancery and the adoption of setoff statutes by the American colonies).

21 Comment, Setoff in Bankruptcy: Is the Creditor Preferred or Secured?, 50 U. Colo.

L. REv. 511, 511 (1979).

${ }^{21}$ See, e.g., Greene v. Darling, 10 F. Cas. 1144, 1146-49 (C.C.D.R.I. 1828) (No. 5765) (Story, J.) (courts of equity will set off debts on grounds of "natural justice").

${ }_{23}$ Bankruptcy Act, ch. 19, § 42, 2 Stat. 19, 33 (1800) (repealed by Act of Dec. 19, 1803, ch. 6, 2 Stat. 248).

24 Bankruptcy Act, ch. 9, § 5, 5 Stat. 440, 445 (1841) (repealed by Act of March 3, 1843, ch. 82, 5 Stat. 614); Bankruptcy Act, ch. 176, $\S 20,14$ Stat. 517, 526 (1867) (repealed by Act 
Despite its heritage, the setoff right is not wholly consistent with the aims and purposes of bankruptcy law. Bankruptcy law is obviously designed in part to provide time for a debtor firm that is unable to meet its obligations and that seeks either to liquidate its assets or, in the appropriate case, to reorganize itself. ${ }^{25}$ Bankruptcy law, however, also seeks to assure an equitable distribution of what may be an insufficient fund to all creditors with valid claims. Under the present statute, the Bankruptcy Reform Act of 1978 (the Bankruptcy Code), ${ }^{26}$ creditors are classed hierarchically; each creditor within a class receives the same pro rata share of the bankrupt's estate. ${ }^{27} \mathrm{By}$ this means, no single creditor or group of creditors is unjustifiably preferred over another. ${ }^{28}$ This collective system eliminates the costs of a race to the courthouse by individual creditors and of a piecemeal dismantling of the debtor's estate. ${ }^{29}$ To the extent that the bankruptcy regime, with its pervasive disfavor of preferential payments, avoids such costs, it seems likely that in the absence of prohibitive negotiation costs creditors bargaining ex ante would prefer such a collective system..$^{30}$ In contrast to this pro rata scheme, a creditor who is in a position to exercise a setoff right may recover his claim independently of his place in the bankruptcy hierarchy. As a result, the proportion that he will be able to recover on his claim may exceed the proportionate recovery of other members of his class. ${ }^{31}$ The setoff right effectively elevates an unsecured creditor into a superior class, thus treating him as though he held a functional security interest. ${ }^{32}$ Since the setoff

of June 7, 1878, ch. 160, 20 Stat. 99); Bankruptcy Act of 1898, 11 U.S.C. $\$ 108$ (1976) (repealed by Bankruptcy Reform Act of 1978, Pub. L. No. 95-598, tit. IV, $\S 401,92$ Stat. 2549, 2682); Bankruptcy Reform Act of 1978, 11 U.S.C. $\$ 553$ (1982).

${ }^{23}$ Comment, supra note 21, at 514 n.15, 515 n.22. For a discussion of how to determine when reorganization is appropriate, see Baird \& Jackson, Corporate Reorganizations and the Treatment of Diverse Ownership Interests: A Comment on the Adequate Protection of Secured Creditors in Bankruptcy, 51 U. CHI. L. REv. 97, 109-11 (1984).

${ }^{28} 11$ U.S.C. $\$ \S 101-151,326$ (1982).

${ }^{27}$ See 11 U.S.C. $\S 507$ (1982) (priority of claims in bankruptcy distribution); cf. id. $\S$ $1129(b)(2)$ (defining the fair and equitable requirement for purposes of a reorganization plan as between secured creditors, unsecured creditors and other holders of interests in the estate).

28 Justified grounds for preference include the holding of a security interest or a bargained-for superior position vis-a-vis other unsecured creditors; both are recognized in the Bankruptcy Code's hierarchy of classes of creditors. See id. \$§ 507, 1129(b)(2).

29 See Jackson, Bankruptcy, Non-Bankruptcy Entitlements and the Creditors' Bargain, 91 Yale L.J. 857, 859-71 (1982).

so Id. at 860 .

31 See Comment, supra note 21, at 515 \& n.20.

${ }^{32}$ See United States ex rel. Johnson v. Morley Constr. Co., 98 F.2d 781 (2d Cir. 1938). The Morley court observed: "the truth is that after insolvency the counterclaim becomes the 
creditor, unlike a secured creditor, has not bargained for superior status prior to bankruptcy, this result appears to prefer the setoff creditor over other creditors unjustifiably.

Despite this inconsistency between the setoff right and the collective insolvency scheme, the Bankruptcy Code preserves the remedy in section 553. ${ }^{33}$ The authority of section 553, however, does not extend to an insolvent bank. According to the explicit terms of section 109 of the Bankruptcy Code, "a . . . bank, savings bank, cooperative bank, savings and loan association, building and loan association, homestead association, or credit union" may not be a debtor for purposes of the Code. ${ }^{34}$ Such institutions, Congress believed, were best left outside the scope of the Bankruptcy Code because they are bodies whose insolvency and liquidation is governed by other state or federal law..$^{35}$

The exclusion of bank failures from the Bankruptcy Code reflects the very different concerns underlying the bankruptcy law and the statutory scheme governing bank failures. ${ }^{36}$ The principal aim of the bankruptcy system is to resolve creditors' claims in an orderly and collective proceeding. ${ }^{37}$ As a means to this end, the debtor's filing for bankruptcy triggers an automatic stay of any pending or imminent actions by creditors. ${ }^{38}$ This mechanism, which has no banking analogue, is designed to give the debtor a breathing spell during which he can formulate repayment or reorganization plans. ${ }^{39}$ The principal aim of the system for handling failed banks, in contrast, is a rapid settlement of depositors'

creditor's security for his own claim, a means by which it can be paid dollar for dollar through his right of set-off." Id. at 790; see also Comment, supra note 21, at 519-26 (observing that in the Bankruptcy Code, 11 U.S.C. $\$ 553$ (1982), setoff is treated as a functional security interest).

ss 11 U.S.C. \& 553 (1982).

s4 11 U.S.C. \& 109(b)(2) (1982).

ss See S. Rep. No. 989, 95th Cong., 2d Sess. 31, reprinted in 1978 U.S. Code Cong. \& Ab. News 5787, 5817; see also Corbin v. Federal Reserve Bank, 629 F.2d 233, 236 (2d Cir. 1980) ("Because the powers and goals of a bank receiver are quite different, equitable principles developed in the reorganization context cannot simply be grafted onto the national banking statutes."), cert. denied, 450 U.S. 970 (1981); First Am. Bank \& Trust Co v. George, 540 F.2d 343, 349 (8th Cir. 1976) (banks are excluded from the bankruptcy laws because they are regulated by other law, are subject to express statutory procedures for liquidation, and are businesses of a public or quasi-public nature involving interests other than those of creditors).

so See infra notes 46-49 and accompanying text.

s7 See supra note 29 and accompanying text.

${ }^{38} 11$ U.S.C. $\$ 362$ (1982).

so S. REp. No. 989, 95th Cong., 2d Sess. 54-55, reprinted in 1978 U.S. CodE Cong. \& AD. NEws 5787, 5840-41. 
claims, ${ }^{40}$ growing out of a concern with preserving public confidence and with limiting the potential "ripple effects"41 of a bank failure-both third-party effects that are of less significance in cases under the Bankruptcy Code. ${ }^{42}$ To ensure immediate recovery by depositors, the FDIC shifts the burden of lengthy liquidation proceedings onto itself. ${ }^{43}$ Under the Bankruptcy Code, by contrast, with its provision for an automatic stay, that burden is borne by the creditors. ${ }^{44}$ Given the disparate aims of the statutory schemes governing bankruptcy and bank insolvency, one must hesitate to draw support for a depositor's right of setoff, even by analogy,

10 See Barnett, Address on Deposit Insurance, in Frderal Deposit Insurance CorpoRation, 1976 Annual Report 160, 161 (submitted to Congress by Robert E. Barnett, Chairman of the FDIC) (observing that "[i]n a deposit payoff, balances in secured and preferred deposits, as well as insured deposits, are paid over to their owners, usually beginning 5 to 7 days following the closing of the bank ...."). In a purchase and assumption transaction, see infra notes 82-89 and accompanying text, the depositor's account is undisturbed.

Holders of uninsured deposits who lack other protection (e.g., a setoff) "must await recovery on their claims from an often lengthy liquidation of the bank's assets and must bear a pro rata share of any loss that ensues." Barnett, supra, at 161.

\$1 See Bransilver, Failing Banks: FDIC's Options and Constraints, 27 AD. L. Rev. 327, 334 (1975). For an analysis of the "ripples" following the Penn Square failure, see, for example, Am. Banker, July 19, 1982, at 4, col. 1 (Dr. P. Nadler of Rutgers arguing that the failure of Penn Square decreased the overall effectiveness of American community banking systems); Wall St. J., July 23, 1982, at 3, col. 1 (noting that one savings and loan association with uninsured deposits in Penn Square was insolvent as a result of Penn Square's failure); Wall St. J., July 22, 1982, at 23, col. 3 (noting that money brokers were affected by Penn Square's failure); Wall St. J., July 12, 1982, at 26, col. 1 (noting that the prices of offerings by banks dropped on the international bond market in the wake of Penn Square's failure). But see Penn Square Hearings, supra note 12, at 63 (William Isaac, Chairman of the FDIC, noting that more prudent behavior by surviving banks is one positive ripple effect following a bank failure).

12 One might argue that insofar as we permit setoff as a remedy under bankruptcy law, then a fortiori we should permit it in the context of a bank insolvency, provided that it does not interfere with other bank regulatory policies. To the extent, however, that the availability of setoff is not wholly consistent with the purposes of bankruptcy law, see supra notes 30-33 and accompanying text, it seems best to avoid the a fortiori argument and to focus primarily on the purposes and effects of the remedy in the narrower context of bank insolvency.

13 The anxiety of depositors is illustrated in the following account of an encounter occurring just after the failure of Penn Square became public knowledge:

There was a young blonde-haired man, dressed only in a maroon bathing suit and slightly sunburned from the three-day Fourth of July weekend. He leaned against his pickup truck, gazing in disbelief at the Penn Square building. He asked a reporter if he would have to stand in line to get his money, and when told that it really would not be necessary to sleep in his truck, he shouted angrily, "You don't have $\$ 100,000$ in this stupid bank."

Am. Banker, July 7, 1982, at 15, col. 1 .

14 Secured creditors are assured adequate protection of the value of their collateral during the period of the automatic stay. See 11 U.S.C. $\$ 361$ (1982). As this statutory section has been applied by the courts, however, even secured creditors have been made to bear the cost of bankruptcy proceedings. See Baird \& Jackson, supra note 25, at 98-99. 
from the existence of such a right under the Bankruptcy Code. ${ }^{45}$ At this juncture the analyses of setoff in bankruptcy and of depositor setoff must diverge to take account of the very different aims of the two insolvency systems.

\section{B. Setoff and Banking Law}

Two provisions of the National Bank Act (NBA) ${ }^{46}$ establish the basic statutory framework for bank liquidation. Under section 91, all transfers made to or from a bank in contemplation of its insolvency and "with a view to the preference of one creditor to another. . . [are] utterly null and void."47 Section 194, the Act's principal rule for the payment of claims against an insolvent bank, ${ }^{48}$ authorizes the Comptroller of the Currency to pay a "ratable dividend" out of money paid to him by the receiver of the failed bank "on all such claims as may have been proved to his satisfaction or adjudicated in a court of competent jurisdiction."48 These two provisions together establish that a bank liquidation is fundamentally to be a collective proceeding in which depositors are treated equally. ${ }^{\text {so }}$

The statute's strong proscription of preferential distributions

48 The wish to provide a breathing spell and the contrary wish to settle the insolvent's affairs as quickly as possible are present under both bankruptcy law and the law governing bank insolvencies; the policy favoring speed simply weighs more heavily in the case of bank failure, especially insofar as depositors are concerned. For reasons discussed infra notes 13645 and accompanying text, this comment focuses on the interests of depositors as against those of nondepositor creditors.

48 National Bank Act, ch. 106, 13 Stat. 99 (1864) (current version at 12 U.S.C. $\S \S 21-$ 216b (1982)).

412 U.S.C. $\$ 91$ (1982). The section also bars any transfer designed to prevent "the application of [the bank's] assets in the manner prescribed by this chapter." Id.

18 Id. § 194; see also Uhl v. First Nat'l Bank \& Trust Co., 24 F. Supp. 275, 275, 279-81 (W.D. Mich.) (noting the important purposes of 12 U.S.C. $\$ \S 91,194)$, aff'd 94 F.2d 1013 (6th Cir.), cert. denied, 304 U.S. 584 (1938).

49 12 U.S.C. \$ 194. Any funds remaining in the receivership following the satisfaction of proven claims are to be paid to the shareholders of the liquidated bank. Id.

so While this comment focuses primarily on national banks, the analysis proposed is equally applicable to state banks. In the case of the insolvency of a state bank, state banking statutes govern the scope of a depositor's setoff right. The vast majority of those statutes reflect the provisions of the National Bank Act both in their silence on setoff and in their antipathy to preferences. See, e.g., Ill. Rev. Stat. ch. 17, § 371 (1983) (notice of receivership); Mich. Comp. Laws ANN. $\S 487.552$ (West Supp. 1983) (powers and duties of receivership); Minn. Stat. AnN. $\$ 49.24$ (West 1970) (procedure in liquidation). New Jersey specifically authorizes the commissioner, on taking possession of an insolvent bank, to "[m]ake or allow proper set-offs," N.J. STAT. ANN. § 17:9A-272(A)(4) (West Supp. 1983), but the question of whether a setoff is "proper" remains one for judicial decision in light of common law precedents. For a discussion of the somewhat confused state of the law in New York, see infra note 127. 
can be read as barring setoff, since that remedy affords a potentially greater proportional recovery to those depositors to whom it is available. ${ }^{51}$ This reading is strengthened by the fact that the NBA nowhere authorizes setoff against an insolvent bank. Yet the Federal Deposit Insurance Act (FDIA) does provide some authority to the contrary. The FDIA defines an "insured deposit" as "the net amount due to any depositor ... for deposits in an insured bank (after deducting offsets) less any part thereof which is in excess of $\$ 100,000$." $"$ This definition contemplates the calculation of a depositor's insured deposit only after any available setoff has been taken. Thus, if a depositor's total deposit is $\$ 120,000$ and his corresponding liability to the bank is $\$ 60,000$, this method of calculation assures that such a depositor will recover in full ${ }^{53}$ while a depositor with the same account balance but no setoff must bear the risks of recovering his uninsured $\$ 20,000$ from the liquidation proceeds. ${ }^{54}$ The FDIA, then, seems to contemplate unequal recovery among different classes of depositors depending upon the character of their dealings with the insolvent bank. However, the FDIA defines "insured deposit" for purposes of that Act only, and while both the FDIA and the NBA arguably reflect a common regulatory scheme for dealing with an insolvent bank, the rather offhand reference to offset in the FDIA is a weak base on which to build a statutory argument. The FDIA provides at best indirect guidance as to whether a setoff is a preferential distribution inconsistent with section 194 of the NBA.

\section{Scott v. Armstrong}

In the absence of any definitive provision in the federal banking statutes either authorizing or prohibiting setoff against an insolvent bank, ${ }^{\text {s8 }}$ courts have relied on their equitable powers to grant setoff against an insolvent bank ${ }^{\mathrm{BB}}$ and have founded their

s1 See supra notes 31-32 and accompanying text.

s2 Federal Deposit Insurance Act, 12 U.S.C. § 1813(m)(1) (1982); see supra notes 1-3 and accompanying text.

ss Federal Deposit Insurance Act, 12 U.S.C. \& 1821(f) (1982).

st The depositor with the $\$ 60,000$ liability subtracts $\$ 60,000$ from $\$ 120,000$ leaving him with a $\$ 60,000$ deposit, which would be fully covered under the $\$ 100,000$ insured limit. The depositor without setoff is covered for his first $\$ 100,000$, but recovery of the remaining $\$ 20,000$ will depend on the results of the liquidation.

ss See supra notes $39-50$ and accompanying text.

ss See, e.g., Whitaker v. Cush, Amb. 407, 407-08, 27 Eng. Rep. 272, 273 (Ch. 1761) ("It was a rule of justice to set one debt off against another, in the Roman law.... That rule did not prevail in England for many years. . . . Equity took it up."). 
holdings on the 1892 decision of the Supreme Court in Scott $v$. Armstrong. ${ }^{57}$ The defendant in Scott, Farmers' and Merchants' State Bank, received a loan from the Fidelity National Bank to be recorded on Fidelity's books to Farmers' account. Farmers' was obligated to repay the amount borrowed in ninety days. ${ }^{58}$ Two weeks after the loan was executed and over two months before it was to mature, Fidelity was closed by order of the bank examiner and a receiver was appointed. At the time Fidelity failed, all but approximately $\$ 1000$ of the loan amount remained credited to Farmers' account. When the loan matured, Farmers' tendered the difference between the loan amount and the amount credited to its account and claimed a setoff of the amount remaining credited to its account when Fidelity became insolvent. ${ }^{59}$ Rejecting the receiver's argument that Farmers' could not set off the amount remaining to its credit on Fidelity's books because its obligation to repay remained unmatured at the time of Fidelity's closing, the Court held that neither equity ${ }^{60}$ nor the NBA $^{61}$ barred Farmers' setoff. The Court acknowledged that "[t]he right to assert set-off at law is of statutory creation," but noted that courts of equity "from a very early day" have been "accustomed to grant relief in that regard independently as well as in aid of statutes on the subject." The Court suggested that the dealings between Farmers' and Fidelity raised "the presumption of an agreement for a set-off, which equity should honor." ${ }^{\text {s3 }}$ In response to the receiver's argument that the setoff by Farmers' constituted a preference in violation of the NBA, the Court reasoned that implied agreements made "prior to insolvency and not in contemplation thereof" Consequently, the Court concluded, the "greater payments" permitted to those depositors who could set off certain liabilities were not preferences. Finally, the Court reasoned that the amount set

${ }^{87} 146$ U.S. 499 (1892) (Fuller, C.J.) (9-0 decision).

s8 Id. at 500 .

${ }^{80} \mathrm{Id}$. at 501 .

${ }^{60} \mathrm{Id}$. at 508.

${ }^{81}$ Id. at 509-11. The provisions of the National Bank Act at issue in Scott, U.S. REv. STAT. $\S 5236,5242(1878)$, were identical to those now codified in 12 U.S.C. $\S \S 91,194$ (1982). See infra note 69 and accompanying text.

${ }^{62}$ Scott, 146 U.S. at 507.

${ }^{63}$ Id. at 508. The Court also concluded that, although the loan had not matured at the time of Fidelity's failure, the mutual obligations between the parties justified upholding the setoff in equity. For further discussion of the maturity requirements, see infra note 127. For further discussion of the mutuality requirement, see infra notes 125-30 and accompanying text.

64 Scott, 146 U.S. at 510. 
off could not constitute part of the bank's assets, because that amount was in fact an asset of the depositor. ${ }^{\text {BS }}$ Therefore, the Court held that permitting setoff would satisfy the requirement of the NBA that the assets of the insolvent bank be ratably distributed among the creditors. ${ }^{66}$

Two features of the Scott Court's reasoning deserve attention. First, the holding could be limited to transactions in which the credit and debt are so interdependent as to be effectively elements of a single transaction. The credit Farmers' sought to apply to its obligations was an account that arose at the time and as a result of Farmers' borrowing from Fidelity. The Court, however, declined to decide the question narrowly, stating the principle of the case in broad terms of equity and natural justice:

Indeed natural justice would seem to require that where the transaction is such as to raise the presumption of an agreement for a set-off it should be held that the equity that this should be done is superior to any subsequent equity not arising out of a purchase for value without notice. ${ }^{67}$

The Court provided little indication of precisely what constitutes a transaction sufficient to raise a presumption of agreement, but this very vagueness, in conjunction with the Court's emphasis on equitable considerations, has fostered the belief that even in cases where the mutual credits are wholly independent, the depositor may assert a right of setoff. ${ }^{68}$

Second, despite the Court's emphasis on equity and natural justice, the Scott decision is technically a holding under provisions of the NBA. ${ }^{8 \theta}$ The receiver of Fidelity challenged Farmers' setoff as invalid under the prohibition against preferential distributions ${ }^{70}$ and the requirement of ratable distribution. ${ }^{71}$ While the Court held

Bs Id.

is.

67 Id. at 508.

a For a compendium of cases generally supporting the setoff rule, see 5A A. MrchIE, supra note 18 , at $\S 155$.

60 The original act was entitled, "An Act to provide a National Currency secured by a Pledge of United States Bonds, and to provide for the Circulation \& Redemption thereof." Act of June 3, 1864, ch. 106, 13 Stat. 99. The Act was retitled the "National Bank Act" by the Act of June 20,1874 , ch. $343, \S 1,18$ Stat. 123. The Act's pertinent sections, 50 and 52 , National Banking Act, ch. 106, $\S$ 50, 52, 13 Stat. 99, 115, 116 (1864), were incorporated into the Revised Statutes of 1878 as U.S. REv. STAT. $\$ \S 5236,5242$ (1878). These are the provisions on which the Scott court relied. They are identical to the original 1864 provisions and to the current provisions of the National Bank Act, codified at 12 U.S.C. $\$ \S 91,194$ (1982).

70 U.S. REv. STAT. \$ 5242 (1878) (currently codified at 12 U.S.C. \$ 91 (1982)).

${ }^{71}$ U.S. REv. STAT. $\$ 5236$ (1878) (currently codified at 12 U.S.C. $§ 194$ (1982)); see 
that neither of these provisions prevented the setoff, it did so in a conclusory manner, without examining the statutory language and without any attempt to fathom congressional intent. ${ }^{\mathbf{2 2}}$

Given the emphasis of the Scott opinion on equity rather than on the language of the statute, it is not surprising that the Court's dicta about the equity of setoff have proved far more influential than its narrow holding. Courts have relied on Scott for the presumption that a depositor in a failed bank may always set off his deposit against an outstanding obligation. ${ }^{33}$ In Chase Manhattan Bank v. FDIC, ${ }^{74}$ the court dismissed the claim that the Penn Square setoffs were wrongful in conclusory fashion: "The borrower's right to offset is not in issue. Scott $v$. Armstrong establishes the right of a depositor in an insolvent bank to set-off any deposits against indebtedness owing to the bank."7s Even if one is disposed to accept the $S$ cott dicta as correct, the question that the Scott Court did not clearly address must still be answered: why is it correct?

\section{The Rationale for Setoff}

The Scott court justified the setoff rule on grounds of equity and natural justice. ${ }^{76}$ One important subsequent justification for the setoff rule, not available to the Scott Court in 1892,77 is the significant role played by the FDIC in virtually every bank failure. ${ }^{78}$ Whether the insolvent bank is a national ${ }^{79}$ or a state bank, ${ }^{80}$

Scott, 146 U.S. at 505-06 (summary of counsel's argument for Fidelity). The statutory language, identical to that currently in effect and quoted supra notes 46-50 and accompanying text, was quoted by the Court. Scott, 146 U.S. at 509-10.

72 "The provisions of the act," the Court held in conclusory fashion, "are not directed against all liens, securities, pledges or equities, whereby one creditor may obtain a greater payment than another, but against those given or arising after or in contemplation of insolvency." Scott, 146 U.S. at 510.

${ }^{73}$ See, e.g., FDIC v. Mademoiselle of Cal., 379 F.2d 660, 663 (9th Cir. 1967) (after Scott, equitable setoff is allowed under the NBA); First Nat'l Bank v. Malone, 76 F.2d 251, 254 (8th Cir. 1935) (citing Scott for the proposition that courts of equity may deviate from the strict rule of mutuality when justice so requires); Bromfield v. Trinidad Nat'l Inv. Co., 36 F.2d 646, 648 (10th Cir. 1929) (Scott settles "that a receiver of a national bank, when suing the maker of a note to the bank, must set off the amount of the maker's deposit, without an express agreement").

${ }^{34} 554$ F. Supp. 251 (W.D. Okla. 1983).

${ }^{75}$ Id. at 254 (citation omitted).

${ }^{76}$ See supra text at note 67.

77 See supra note 1.

${ }_{78}$ As of December 31,1981 , only 481 of 14,882 commercial banks, holding slightly over one percent of the total national commercial banking deposits, were not insured by the FDiC. Statistical Abstract of the United States 1982-83 at 504 (Table No. 827, Commercial Banks-Summary, by Class of Bank: 1970 to 1981). 
the FDIC will very likely act as its receiver. ${ }^{81}$ The FDIC in its role as receiver has two methods of handling a bank failure; the preferred method is to arrange a purchase and assumption transaction in which the failed bank, with FDIC assistance, is merged into another, healthier institution..$^{82}$ Alternatively, the FDIC can arrange a payoff and liquidation, wherein insured depositors are paid off at

79 Under the present regulatory system of dual banking, banks may be either national banks or state banks. National banks are chartered by the Comptroller of Currency and automatically become members of the Federal Reserve System. 12 U.S.C. \$§ 21-27 (1982); see also J. Culbertson, Monky \& BANkIng 165 (1972). As member banks, they must be insured by the FDIC. 12 U.S.C. $\$ 1814$ (b) (1982).

so State banks are chartered by state bank officials and may voluntarily become members of the Federal Reserve System, 12 U.S.C. $\$ \$ 321-28$ (1982), whereupon they, too, must be insured by the FDIC. 12 U.S.C. \& 1814(b) (1982). State-chartered banks that are not members of the Federal Reserve System may nevertheless choose to be insured by the FDIC, 12 U.S.C. \& 1815 (1982), though state nonmember banks may operate without federal deposit insurance. For a discussion of the dual banking system and its consequences for regulation, see Scott, The Dual Banking System: A Model of Competition in Regulation, 30 StAN. L. Rev. 1, 1-40 (1977).

81 The FDIC exists in two capacities. The agency exists first as a corporation and has a consequent interest in preserving its corporate assets. See 12 U.S.C. § 1823 (1982). The FDIC is also empowered to act as a receiver under 12 U.S.C. $\$ \S 1821(\mathrm{c})-(\mathrm{g}), 1822$ (1982). The Comptroller of Currency is required by statute to appoint the FDIC as receiver for any failed national bank. 12 U.S.C. $\$ 264(i)(1)$ (1982). The FDIC is mandated by statute to act as receiver for any insured state bank when so requested by the appropriate state official. 12 U.S.C. $\$ 1821$ (e) (1982). In practice state banking authorities always make such a request and may even be specifically authorized to do so by state statute. See, e.g., Conn. Gen. STAT. ANN. § 36-36(a) (West 1981); N.J. STAT. ANN. § 17:9A-272A.(1)(d) (West Supp. 1982); N.Y. BANKING LAW \& 634 (McKinney Supp. 1982).

${ }^{82}$ See Penn Square Hearings, supra note 12, at 57-58; see also Barnett, supra note 40, at 161 (noting that a purchase and assumption transaction in fact protects the "going-business" or goodwill value of the failed bank); Bransilver, supra note 41, at 331-34 (noting that over half of all bank failures are handled by purchase and assumption). The FDIC's ability to arrange a purchase and assumption transaction in cases where the failed bank has substantial contingent liabilities may be limited. See infra notes 110-16 and accompanying text.

A purchase and assumption entails four principal steps. First, the FDIC transfers to the acquiring bank all of the failed bank's deposits and commercial obligations. Second, in order to compensate the acquiring bank for assuming those liabilities, the FDIC transfers to the acquiring bank a package of the failed bank's assets-a package that typically excludes nonperforming assets, which the acquiring bank is unwilling to assume. Third, the acquiring bank pays a premium to the FDIC reflecting the goodwill or going-concern value that derives from preserving to a large extent the integration between the assets and liabilities of the failed institution. To the extent that this premium is less than the difference in value between the liabilities transferred in step one and the assets transferred in step two, the FDIC must make up the difference from its insurance trusts. Fourth, the FDIC retains and liquidates those assets not transferred to the acquiring bank. The proceeds of the liquidation are used to reimburse the FDIC for any disbursements from its insurance trusts as well as to meet the claims of any remaining creditors of the receivership, who will principally be holders of equity interests. See Barnett, supra note 40, at 161; Bransilver, supra note 41, at 331-34. For a discussion of the role of contingent liabilities in a purchase and assumption transaction, see infra note 113 and accompanying text. 
the time of the bank failure and the rest of the bank's assets are liquidated and divided pro rata among uninsured depositors and other creditors, each bearing a proportionate share of the loss. ${ }^{83}$ Setoff plays an important part in determining whether a purchase assumption transaction can be arranged. ${ }^{84}$

A purchase and assumption is the preferred means of handling a bank failure because it allows the FDIC to minimize the attendant losses and disruptions. First, the personnel and facilities of the insolvent institution typically change little at the time of the takeover. ${ }^{85}$ Second, to the extent that the acquiring bank purchases most of the failed institution's assets, its accounts remain intact, preserving the existing relationship between loans and deposits. ${ }^{86}$ The bargain originally struck between the bank and its customers is least disrupted by a plan that preserves, as far as possible, the integrity of the failed institution's accounts. ${ }^{87}$ Third, a purchase and assumption transaction preserves the failed bank's going-concern value. ${ }^{88}$ Most important, however, given the FDIC's mandate to preserve confidence in the banking system, a purchase and assumption transaction has typically afforded depositors full protection, even for uninsured deposits. ${ }^{88}$

In a payoff and liquidation, by contrast, the integration of loans and deposits is severed since recovered deposits are shifted to other institutions while the loans remain as assets of the receivership, over which the FDIC presides. ${ }^{80}$ Thus, the initial bargain struck between the bank and its customers is disrupted and the

${ }^{83}$ National Bank Act, 12 U.S.C. § 194 (1982); see also Barnett, supra note 40, at 161 (noting that liquidation proceedings are often lengthy).

se Se infra notes 89-109 and accompanying text.

${ }^{8 s}$ Barnett, supra note 40, at 161 .

Id.

87 Id.

ss Id. The premium paid to the FDIC by the acquiring bank in a purchase and assumption reflects this value of keeping together the failing institution's assets and liabilities. See supra note 82 .

89

The high recovery rate for depositors [in banks failing in 1976] is attributable at least in part to the fact that $\$ 9$ out of every $\$ 10$ in deposits were in bank failures which were handled by purchase and assumption transactions .... This arrangement provides, in effect, 100 percent insurance to uninsured depositors and general creditors as well as to FDIC-insured depositors. If one or more of the large bank failures . . . had been paid off, the number of depositors not having de facto 100 percent insurance would have been substantially larger.

Barnett, supra note 40 , at 160 . Recent action by the FDIC suggests that de facto $100 \%$ insurance in purchase and assumptions is no longer assured. See infra note 94.

${ }^{\circ}$ Id. at 161. 
bank loses its going-concern value. ${ }^{91}$ Moreover, customers with deposits in excess of the insured limit of $\$ 100,000$ must depend upon the often lengthy liquidation proceedings in order to recover, ${ }^{92}$ and to the extent that the liquidation value of the assets falls short of the outstanding claims, they must bear a pro rata share of the loss. ${ }^{.3}$ The FDIC estimates that in a payoff and liquidation, uninsured depositors typically lose twelve percent of their individual deposits. ${ }^{94}$

Setoff is important to the FDIC not only because it can reduce the amount that the agency must pay out to depositors in a payoff and liquidation, ${ }^{95}$ but also because it can facilitate a purchase and

91 Id.; Penn Square Hearings, supra note 12, at 59; Bransilver, supra note 41 at 334.

92 For a national bank, section 194 of the NBA, 12 U.S.C. $\$ 194$ (1982), provides for a recovery of deposits from ratable dividends paid by the receiver during the course of liquidating the bank's assets. State banking statutes contain similar provisions. See, e.g., ILL. Rev. Stat. ch. 17, § 377 (1983); Mich. Comp. Laws ANN. § 487.552 (West Supp. 1983); MinN. Stat. AnN. \& 49.24 (West 1970).

's It is important to remember in calculating the risk of such a loss that the proceeds of the asset liquidation are applied not only to uninsured deposits and claims by general creditors but also to insured deposits paid off by the FDIC. Under section 1821(g) of the FDIA, 12 U.S.C. $\S 1821(\mathrm{~g})(1982)$, the FDIC is subrogated to the insured claim of any insured depositor against the bank. The cost of recovering from the liquidation proceeding also entails the loss of interest for the period of the liquidation on the amount to be recovered. See Barnett, supra note 40 , at 160 .

9 Barnett, supra note 40 , at 160 . More recent informal estimates have indicated that uninsured depositors recover $98 \%$ of their uninsured deposits after a purchase and assumption. N.Y. Times, June 18, 1983, $\$ 4$, at 31, col. 1 (quoting Thomas Procopio, FDIC liquidator). By contrast uninsured depositors in Penn Square were expected to recover only about $65 \%$ of their uninsured deposits. Id. In early 1983, the FDIC proposed limiting all payments over $\$ 100,000$ to 75 cents on the dollar, even in purchase and assumption transactions, N.Y. Times, March 16, 1983, § 4, at 4, col. 1, and in early 1984 the FDIC announced, upon the failure of two banks, that even if purchase and assumptions were arranged, the depositors with accounts over $\$ 100,000$ could not expect to be fully protected. Wall St. J., March 19, 1984, at 3, col. 3. The FDIC explicitly stated that its purpose was to "avoid the unintended effect of providing $100 \%$ protection to uninsured depositors." Id. Until the Penn Square failure and the recent movement to limit recovery on uninsured deposits in purchase and assumptions, the FDIC had sought to minimize these losses to holders of uninsured deposits by reserving the payoff and liquidation remedy for small bank failures where few deposits exceed the $\$ 100,000$ limit. See generally Skillern \& Topelius, FDIC Makes Unusual Payoff in Penn Square Failure, Legal Times, July 19, 1982, at 15, col. 1 (noting the use of the Deposit Insurance National Bank to pay off the depositors in Penn Square). This limited use of the payoff remedy and the preference for purchase and assumption transactions contributed to "the belief that the system affords de facto 100 percent deposit insurance for deposits in large banks." Id. The FDIC itself boasted that "[a]bout 99.8 percent of all depositors, large or small, fully recovered their deposits almost immediately, with only onetenth of 1 percent having to wait for the liquidation of bank assets." Barnett, supra note 40, at 160. Given such remarks, made less than ten years ago, the recent movement to impose on uninsured depositors some portion of the burden of monitoring bank soundness appears to reflect something of a change of policy on the part of the FDIC. See infra note 133.

os See, e.g., infra note 154 and accompanying text (using the Penn Square payout as an 
assumption transaction. According to the terms of the FDIA, the FDIC shall provide no financial assistance to facilitate arranging a purchase and assumption transaction "in excess of that amount which the [FDIC] determines to be reasonably necessary to save the cost of liquidating, including paying the insured accounts of, such insured bank . . . ."98 In other words, the FDIC may promote a purchase and assumption transaction only if it will be less costly to the FDIC than a payoff of insured deposits followed by a liquidation of assets. ${ }^{97}$ In order to determine which remedy will be more costly, the FDIC first estimates the insured and uninsured shares of the loss expected to result from the insolvency. ${ }^{98}$ Since in a purchase and assumption transaction the FDIC effectively assumes the entire loss, ${ }^{9 \theta}$ the excess cost of such a transaction over a payoff and liquidation is equal to the uninsured portion of the loss. ${ }^{100}$ After deducting from that amount the administrative cost of an insured deposit payoff, ${ }^{101}$ the FDIC is left with a sum which must be made up in some fashion to justify a purchase and assumption. ${ }^{102}$ Banks seeking to acquire the assets and liabilities of the failed institution submit bids, and if one or more of the premi-

example).

12 U.S.C. \& 1823(c)(4)(A) (1982). This provision, enacted as part of the Garn-St. Germain Depository Institutions Act of 1982, Pub. L. No. 97-320, tit. I, § 111(c)(4)(A), 96 Stat. 1469,1470 , added a new measure of flexibility, to the FDIC's ability to facilitate the merger of a failed bank with a healthy one. Under the previous standard, the FDIC could provide such assistance only to "reduce the risk or avert a threatened loss to the [FDIC]." 12 U.S.C. § 1823(e) (1976). In addition to stating what appears to be a new standard for assessing the benefit of assistance to facilitate a merger, $\S 1823(\mathrm{c})(4)(\mathrm{A})$ also provides that the FDIC may provide assistance in excess of the cost of payoff and liquidation "in any case where the [FDIC] determines that the continued operation of [the failed bank] is essential to provide adequate banking services in its community." 12 U.S.C, $\$ 1823$ (c)(4)(A) (1982). Despite the added flexibility, the new statute requires essentially the same balancing of costs as the old one, and the ensuing discussion assumes that the FDIC will perform that balancing in the future much as it did in the past. For a discussion of how that balancing was done under $\S 1823(\mathrm{e})$, see Barnett, supra note 40, at 162-63.

${ }^{97}$ See Barnett, supra note 40, at 162.

os Id.

20 To the extent that in arranging a purchase and assumption the FDIC has provided de facto $100 \%$ deposit insurance, see supra note 94 , it has taken upon itself the share of loss that would otherwise be borne by uninsured depositors. Recent efforts to limit recoveries by uninsured depositors in purchase and assumptions, see id., will have the effect, of course, of reducing the share of loss borne by the FDIC by shifting it back onto the uninsured depositors. For a description of a purchase and assumption transaction, see supra note 82.

${ }^{100}$ Barnett, supra note 40 , at 162.

101 Id.

102 This sum to be made up will be reduced, thereby increasing the likelihood of arranging a purchase and assumption transaction, if the FDIC adopts the policy of limiting the recovery of uninsured depositors in a purchase and assumption to something less than $100 \%$ of their uninsured deposits. See supra note 94. 
ums $^{103}$ offered matches or exceeds the amount to be made up, then the FDIC may proceed to arrange a merger. ${ }^{104}$ If a substantial portion of the uninsured deposits may be set off against outstanding loan obligations, then the uninsured portion of the expected loss may be significantly reduced, in turn reducing the size of the premium necessary to justify a purchase and assumption transaction. ${ }^{105}$

An example will best illustrate this point. ${ }^{106}$ Assume that a bank fails with deposits of $\$ 100$ million of which $\$ 75$ million are insured. If the bank's assets are valued at $\$ 80$ million, thereby giving rise to a $\$ 20$ million expected loss, then, in a payoff and liquidation, the FDIC will pay off the $\$ 75$ million of insured deposits and be subrogated to the insured depositors' claims. Since its subrogated $\$ 75$ million claim against the assets of the bank is $75 \%$ of the outstanding claims, it will receive $\$ 60$ million of the banks assets and suffer a $\$ 15$ million loss. The uninsured depositors will receive $\$ 20$ million and suffer a $\$ 5$ million loss in accordance with their $25 \%$ share of the claims against the banks assets. In a purchase and assumption transaction, the FDIC will assume the entire $\$ 20$ million loss. Therefore, a premium of $\$ 5$ million will be necessary to justify a purchase and assumption transaction. Assume, however, that $\$ 15$ million of the bank's assets are loans to uninsured depositors. If the uninsured depositors can set off those loans, the failed bank's liabilities would effectively be reduced to $\$ 85$ million, $\$ 75$ million of which would continue to be insured deposits and $\$ 10$ million of which would be uninsured deposits; its assets would effectively be reduced to $\$ 65$ million. In a payoff the FDIC would again pay off the $\$ 75$ million of insured deposits and be subrogated to the insured depositors' claims. However, since $\$ 75$ million is $88.2 \%$ of the outstanding $\$ 85$ million of claims the FDIC will receive $\$ 57.33$ million on its $\$ 75$ million claim and suffer a $\$ 17.64$ million loss. The uninsured depositors will receive $\$ 7.67$ million on their $\$ 10$ million deposits and suffer a $\$ 2.36$ million loss. The premium now necessary to justify a purchase and assumption transaction is only $\$ 2.36$ million. ${ }^{107}$

${ }^{103}$ For a description of the economic import of these premiums, see supra note 82.

104 Barnett, supra note 40, at 162.

108 Id. at 163.

${ }^{108}$ The following hypothetical is adapted from id. at 162-63.

107 While allowing the setoffs increases the likelihood that a purchase and assumption can be justified under the statutory standard, the action also increases the share of the anticipated loss borne by the FDIC as subrogee of the depositors' claims against the bank. 12 U.S.C. § $1821(\mathrm{~g})$ (1982); see infra notes $123-45$ and accompanying text (discussing the 
The advantage of setoff to the depositor in the existing regulatory setting is apparent. The right effectively serves as a self-insurance mechanism for deposits in excess of the FDIC's $\$ 100,000$ limit. A depositor may structure his private dealings with the bank to assure that he will suffer no loss even in the eventuality of a payoff and liquidation. Indeed, customers currently tend to withdraw uninsured deposits from a bank known to be in trouble, leaving only balances protected by an offset or by preferred status. ${ }^{108}$ When the Franklin National Bank failed in 1974, for example, the FDIC found that approximately $75 \%$ of the uninsured demand deposits were protected by loan offsets. ${ }^{100}$ This substantial figure suggests action by depositors, whether in their original dealings with the bank or in the weeks before the bank failed, to use their right of setoff as a surrogate for deposit insurance.

Because bank failures have been relatively rare and because the FDIC has been able to provide virtually $100 \%$ deposit insurance, ${ }^{\mathbf{1 1 0}}$ depositors have had little reason to dwell upon the deposit protection implicit in the setoff right. ${ }^{111}$ The FDIC itself only discovered the importance of including setoffs in purchase and assumption premium calculations when the Franklin National Bank failed in $1974 .^{112}$ But as the likelihood increases that the FDIC will handle a bank failure by means of a payoff and liquidation, ${ }^{113}$

propriety of this shifting of losses to the bank's general depositors and by subrogation to the FDIC).

${ }^{108}$ See Barnett, supra note 40 , at 163.

${ }^{100} \mathrm{Id}$.

${ }^{110}$ Id. at 160 . This trend may be changing, however. See supra note 94.

111 Most of the cases specifically involving setoff disputes date from the 1930's. See A. MrchIE, supra note 18 , at $\S 155$. In the past 20 years, the only significant case involving setoff was FDIC v. Mademoiselle of Cal., 379 F.2d 660 (9th Cir. 1967), discussed infra text accompanying notes 156-167.

${ }^{112}$ See Barnett, supra note 40 at 163.

113 See generally Skillern \& Topelius, supra note 94 (arguing that the holding in First Empire Bank v. FDIC, 572 F.2d 1361 (9th Cir.), cert. denied, 439 U.S. 919 (1978), which limits the FDIC's ability to structure purchase and assumption transactions around the failed bank's contingent liabilities, will result in more payoffs, especially where the failed bank has a large amount of contingent liabilities). The number of payoffs in 1983, as of June 25,1983 , was higher than usual: 5 out of 26 failed banks were paid off. N.Y. Times, June 25 , 1983, at A31, col. 2.

The FDIC's increasing use of payoffs may be a reaction to a recent Ninth Circuit decision that had the effect of increasing the FDIC's risk in arranging purchase and assumption transactions. In First Empire Bank, the United States National Bank of San Diego (USNB) failed while holding a substantial number of standby letters of credit that by their terms would mature only if the borrowers were to default. Id. at 1367. Since these letters secured loans to USNB insiders who were widely believed to be responsible for the failure of the bank and unlikely to make payment on the loans, no solvent bank entering into a purchase and assumption agreement wished to assume the liabilities. Id. at 1365. Moreover, the FDIC 
setoff becomes an increasingly important protection for depositors. In the case of the Penn Square failure, for example, the FDIC concluded that the bank's contingent liabilities-including loan participations, standby letters of credit, and irregularities that might give rise to other claims-were too large to permit the accurate appraisal of expected losses ${ }^{114}$ necessary for a purchase and assumption transaction, thereby forcing the FDIC to proceed with a type of payoff and liquidation. ${ }^{115}$ Any uninsured Penn Square depositor who had the protection of a loan offset was plainly in a much better position than one who did not. To the extent that in contemporary economic circumstances substantial contingent liabilities are likely to be involved in any failure of a large bank, the assurance that the FDIC will arrange a purchase and assumption transaction is diminished and the importance to a depositor of his setoff right is correspondingly enlarged.116

was unable to guarantee their payment without failing the statutory requirement that a purchase and assumption be less costly to the FDIC than a payoff and liquidation. Id. at 1364; see supra notes 96-105 and accompanying text. In order to proceed with the purchase and assumption, the FDIC sought to delay payment on the letters until the agency itself had recovered the amount of all insured deposits it had paid off. The Ninth Circuit held that this plan preferred one group of creditors over another, violating the National Bank Act $\S \S 91,194,12$ U.S.C. $\$ \S 91,194$ (1982). Empire, 572 F.2d at 1371. As a result, the FDIC was held liable for the amount of any letters of credit presented for payment. Id. at 1372. If the FDIC cannot segregate contingent liabilities from the bank's other assets and accounts, as the court ordered in Empire, the FDIC is less likely to be able to arrange purchase and assumptions and more likely to rely on the payoff remedy.

${ }^{314}$ See Penn Square Hearings, supra note 12, at 58-59; see also Barnett, supra note 40, at 162 (noting that the FDIC would prefer, and believed at that time that it would be proper, to exclude these contingent liabilities from the calculus); Bransilver, supra note 41, at 337-38 (noting that the contingent liabilities at issue generally include standby letters of credit, claims in pending litigation against the bank brought prior to its closure, subordinated capital notes, and emergency loans made by a Federal Reserve Bank).

${ }^{116}$ The FDIC decided to set up a Deposit Insurance National Bank (DINB) under section 1821(h) of the FDIA, 12 U.S.C. $\S 1821(\mathrm{~h})$ (1976), rather than to conduct a straight payoff in the Penn Square case. FDIC chairman William Isaac described the operation and rationale of the Penn Square DINB as follows:

All insured deposits would be transferred to the DINB, which would continue to honor checks drawn on the Penn Square Bank up to the insured limit and permit an orderly pay off of insured accounts. Uninsured depositors would be issued receiver's certificates for the excess of their accounts over $\$ 100,000$.

... We decided to pay interest on interest-bearing accounts transferred to the DINB for 90 days as an assurance to depositors that there was no need to rush immediately to the bank to withdraw funds. However, it is hoped the 90-day limit will encourage an orderly transfer of funds to other banks within that time.

Penn Square Hearings, supra note 12, at 60.

116 See Skillern \& Topelius, supra note 94, at 15, cols. 3-4; supra note 113. The importance of a depositor's setoff right will be similarly enlarged if the FDIC adopts the policy of limiting a depositor's recovery in a purchase and assumption to something less than $100 \%$ of his uninsured deposits. See supra note 94. 


\section{B. Setoff, Equity, and the Depositors' Bargain}

The Court in Scott $v$. Armstrong, ${ }^{117}$ upheld the preferential setoff remedy in the face of the collective system otherwise mandated by the NBA. ${ }^{118}$ Recognizing the NBA's proscription of preferential distributions, one might argue that, under $S c o t t,{ }^{119}$ setoff should be limited to those cases where the depositor and the bank have specifically agreed that the remedy shall be available. ${ }^{120} \mathrm{Un}$ less so limited, the Scott Court's presumption of an implied agreement might make it far too easy to avoid the collective resolution of claims against the bank. Indeed, one might further argue that even a specific agreement can be voided as a preferential transfer under section 91 of the $\mathrm{NBA}^{\mathbf{1 2 1}}$ to the extent that it is made in contemplation of an impending insolvency and with a view to avoiding the ratable distribution of assets required by section 194. ${ }^{122}$ In the face of such arguments based upon the terms of the governing statutes, how is one to understand the Scott Court's reliance on equity and natural justice to support an implied agreement theory?

A rule barring setoff imposes a burden of asymmetry on the depositor who is also a borrower insofar as it requires him to meet his obligation to the receiver in full when he knows that he will recover only a portion of what is owed to him. ${ }^{123}$ In repaying his debt and then separately recovering only part of his deposit, he is

117146 U.S. 499 (1892).

${ }_{118}$ National Bank Act, ch. 106, $\S \S 50,52,13$ Stat. 114, 115 (1864) (current version at 12 U.S.C. $\$ \S 91,194$ (1982)). For a discussion of these statutory provisions, see supra notes 46 54 and accompanying text.

118 For a discussion of Scott, see supra text accompanying notes 55-75.

${ }^{220}$ A specific agreement to allow setoff makes plain that the remedy was part of the bargain between the parties. Individual depositor-borrowers, who may lack the bargaining power to negotiate a setoff, have little incentive to do so anyway since their deposits are likely to be within the insured limit of $\$ 100,000$. On the assumption that borrowers who keep deposits larger than the insured limit-often institutions, like Chase in the Penn Square situation-can negotiate loans or other setoff devices for themselves, there is no reason why their interests should eclipse the benefit for which the borrower-depositor seeking setoff specifically negotiated.

12112 U.S.C. \& 91 (1982) ("All transfers . . . to any national banking association . . . made after the commission of an act of insolvency, or in contemplation thereof, [or] made with a view to prevent the application of its assets in the manner prescribed by this chapter ... shall be utterly null and void ....".).

${ }^{122} 12$ U.S.C. $\$ 194$ (1982) ("[T]he comptroller shall make a ratable dividend of the money so paid over to him ....").

${ }_{123}$ "Where no superior equities intervene, the set-off of a deposit against the debt upon an unmatured note is allowed upon the theory that in good conscience one ought not to pay his debt to his creditor if he cannot ultimately compel his creditor to pay the debt due him." First Nat'l Bank v. Malone, 76 F.2d 251, 254 (8th Cir. 1935). 
effectively subsidizing the recovery of the general depositors. To taike a simple example, imagine a bank which at the time of its failure has five depositors each with a deposit of $\$ 20,000$. One of these depositors, $A$, is also obligated to the bank in the amount of $\$ 20,000$. The receiver determines that, excluding $A$ 's outstanding obligation, only $\$ 50,000$ will be available to pay off the depositors' claims. If $A$, who has dealt twice with the bank, is not allowed his setoff, then $\$ 70,000$ will be available for collective distribution and each depositor will recover $\$ 14,000$. If, however, the setoff is allowed, depositor $A$ will recover in full while each of the remaining four depositors will recover only $\$ 12,500$.

To say that the depositor denied setoff in the above example "subsidizes" the recovery of the general depositors is to beg a question. Could one not as easily say that the depositor deprived of setoff simply gets no more than he bargained for? Recognizing the existence of the Scott rule, of course, it is not apparent that the bargain between the depositor and the bank excludes setoff. Given the presumption in favor of setoff deriving from Scott, both parties may well have assumed that setoff would be available in the event of the bank's insolvency. But insofar as the present task is to justify the Scott rule as a matter of first principles, it becomes necessary to examine the parties' understandings in the absence of any such reliance on Scott.

The emphasis on equity and natural justice in the Scott Court's reasoning about depositor setoff reflects the origins of the setoff remedy itself. ${ }^{124}$ The emergence of setoff in Anglo-American law is traceable mainly to commonsense notions of fairness and to a desire to avoid multiple lawsuits. ${ }^{126} \mathrm{~A}$ sense of the irreducible substantive and procedural fairness of the remedy is evident, for example, in the following statement attributed to Lord Guildford, Chief Justice of Common Pleas, in 1676:

If there are accounts between two merchants, and one of them become bankrupt, the course is not to make the other, who

124 See Loyd, supra note 20 , at 550. observes:

123 After surveying the developments in both Britain and the American colonies, Loyd

It would be interesting to know whether an impetus was given to the English legislation by the prior colonial acts or whether the legislation on both sides of the Atlantic was the outgrowth of a common feeling of impatience with a practice that no longer appeared rational. But the point is not important. Two distinct motives may be detected; one based on the idea that an injustice is done the defendant in refusing him this privilege, the other that unnecessary lawsuits are a nuisance.

Loyd, supra note 20 , at 562. 
perhaps upon stating the accounts is found indebted to the bankrupt, to pay the whole that originally was entrusted to him, and to put him for the recovery of what the bankrupt owes him, into the same condition with the rest of the creditors; but to make him pay that only which appears due to the bankrupt on the foot of the account; otherwise it will be accounts betwixt them after the time of the other's becoming bankrupt, if any such were. ${ }^{128}$

In its conclusory matter-of-factness, this passage reflects the view that when parties have dealt with one another in such a way as to give rise to mutual credits, ${ }^{127}$ it simply violates one's understand-

128 Anonymous, 1 Mod. 215, 86 Eng. Rep. 837 (C.P. 1676).

127 The requirement that the credits between the parties be mutual is fundamental to the setoff remedy. In any other instance the "common sense view that a man should not be compelled to pay one moment what he will be entitled to recover back the next," Loyd, supra note 20 , at 541 , is simply not implicated. See A. MichIE, supra note 18 , at $\$ 155 \&$ n.26.

A few courts have taken the overly narrow view that since the availability of setoff turns upon the relative rights of the parties at the moment of insolvency, the immaturity of an obligation at insolvency precludes mutuality between the parties. See, e.g., Taylor v. Weir, 63 Ill. App. 82 (1895); Fera v. Wickham, 135 N.Y. 223, 31 N.E. 1028 (1892); In re Anthracite Trust Co., $319 \mathrm{~Pa}$. 113, 179 A. 245 (1935). As a practical matter, this maturity requirement may no longer represent an important limitation on a depositor's right of setoff. The dearth of setoff cases since the 1980's makes it impossible to show a development in the decisions away from the maturity requirement, but some cases and the published commentary indicate a trend in that direction. See, e.g., St. Paul \& M. Trust Co. v. Leck, 57 Minn. 87, 58 N.W. 826 (1894); Davis v. Industrial Mfg. Co., 114 N.C. 321, 19 S.E. 371 (1894); Clark, SetOff in Cases of Immature Claims in Insolvency and Receivership, 34 HaRv. L. REv. 178 (1920); 26 Colum. L. REv. 355 (1926); 14 MinN. L. Rev. 385 (1930).

In at least one jurisdiction the rule that setoff is not available against an unmatured debt owing from the insolvent has been overruled by statute. In New York, under section 151 of the Debtor and Creditor Law, a creditor's right of setoff against an unmatured debt is activated by any one of six occurences, including the appointment of a receiver for the property of the debtor or the filing of an application for such an appointment. N.Y. DeBr. \& Cred. LAW $\S 151$ (McKinney 1945 \& Supp. 1981). As one court noted, the enactment of $\S 151$ "abrogated the old rule that debts which had not matured at the date of adjudication in bankruptcy could not be set off" and brought New York law into harmony with holdings under the federal bankruptcy act according to which the equitable setoff of unmatured claims is allowed. Siegel v. State, 242 A.D. 388, 390, 28 N.Y.S.2d 958, 961 (1941). The New York statute, however, extends the right to set off unmatured indebtedness to cases falling outside the scope of federal bankruptcy law, including, apparently, setoff disputes between a depositor and an insolvent bank.

The maturity date of a note, it is important to remember, designates not the moment when the obligation to pay arises but merely the moment when the money is to change hands. In a case where at the moment of insolvency a depositor is obligated to the bank on a demand note and holds a certificate of deposit maturing sometime in the future, it is plain that the two transactions upon which a setoff claim is based were both fully negotiated in a pre-insolvency world. The bank is no less bound to pay the certificate than the depositor to pay his note. Mutuality between the parties in fact does exist and if setoff is not allowed the two transactions will be asymmetrically resolved. Though there may be a persuasive argu- 
ing of the dealings between them to treat their respective obligatiuns asymmetrically.

This commonsense notion of the fairness of the setoff remedy is reinforced in the context of current law by the fact that the bank has a right of setoff in the event of the depositor's insolvency. ${ }^{128} \mathrm{~A}$ bank will often require a customer seeking a loan to retain a deposit balance in some percentage of the loan amount. ${ }^{129}$ This policy increases the volume of funds on which the bank earns interest, and it provides some assurance that, should the depositor become insolvent, a fund will be available for setoff under the bankruptcy laws. ${ }^{130}$ To the extent that setoff is founded on notions of fairness and symmetry, it follows that a transaction structured to give the bank a setoff right against the depositor should simultaneously give the depositor a setoff right against the bank.

Recognizing, then, that setoff has its origins in the irreducible intuition that it is fundamentally fair to extinguish mutual credits, there is no reason to doubt the existence of a similar intuition in the transactions between a depositor-borrower and a bank. Accordingly, to impose upon a depositor an asymmetrical resolution of his mutual dealings with the insolvent bank may well be to deprive him of a right for which he has, as the Scott Court maintained, implicitly bargained.

\section{Minimizing the Cost of Banking}

To argue that setoff is implicit in the negotiation between the depositor and the bank is only to refute the assertion that a rule against setoff gives the depositor no less than his bargain. That

ment for adjusting the value of the certificate to reflect the loss to the bank resulting from early redemption, there is no basis for contending that it is not available for setoff.

The excessively technical maturity test serves to exclude cases in which the dealings of the parties raise a clear presumption of an agreement for setoff under the broad Scott test. See supra notes 55-75 and accompanying text. Furthermore, the maturity requirement arbitrarily excludes cases in which a depositor denied setoff faces an asymmetrical resolution of his transactions with the bank. The requirement, then, represents a judicial redistribution of rights and risks that runs counter to the allocation that one would expect the parties to make among themselves. See infra notes 131-35 and accompanying text.

12811 U.S.C \& 553 (1982) (state law setoff rights generally preserved in bankruptcy). The legislative history of $\S 553$ makes clear that the provision was intended primarily to address the common practice of banks of setting off a bankrupt depositor's account balance against his outstanding loan obligation to the bank. See H.R. REP. No. 595, 95th Cong., 1st Sess. 184 (1977), reprinted in 1978 U.S. CoDE CoNG. \& AD. NEws 5963, 6144-45.

199 See J. Culbertson, supra note 79, at 143 (noting that the amount of the compensating balance is usually $10 \%$ to $20 \%$ of the amount of the loan).

130 See id. (noting that such "compensating balances" are used for other purposes, such as in place of service charges). 
argument, however, does not answer the charge that setoff constitutes a preference as against depositors who are not in a position to exercise the remedy. One answer to the preference objection is that society values the commonsense fairness of the setoff rule more highly than the benefit of a more perfectly collective system for satisfying claims against a failed bank. The truth of this assertion, however, is difficult to assess. Alternatively, one might ask how those disadvantaged by the setoff rule are likely to regard it. Depositors as a group bargaining ex ante would probably contract for a broad setoff rule despite the fact that depositors without setoff at the time of a bank's failure will take less in a payoff if setoff is permitted. ${ }^{131}$ Without a setoff right, a depositor desiring to have his deposits fully insured would have to open a number of accounts equal to the gross amount of his deposits divided by $\$ 100,000$, the maximum amount insurable per depositor in a given bank under the FDIA; with setoff, that number would be equal to the net amount of his deposits (deposits less bank loans) divided by $\$ 100,000$, a smaller number. For several reasons, the fewer the number of accounts opened, the smaller the total cost imposed on the kank and its customers of maintaining the accounts. ${ }^{132}$

First, there is every likelihood that the aggregate costs of maintaining a larger number of smaller accounts will exceed the costs of maintaining fewer larger accounts. This excess cost is simply a dead-weight loss which the banks will pass on to depositors. Second, such diversification probably will impose increased bookkeeping and monitoring costs on the depositor who must keep track of the status of many deposits and the business fortunes of many banks where with fewer larger deposits he must keep track of fewer of each. ${ }^{133}$ Third, the diversified depositor will give up the

131 Cf. Jackson, supra note 29 , at 860 . An examination of how the parties would allocate rights prior to bankruptcy is a useful way to analyze bankruptcy law's treatment of many nonbankruptcy entitlements.

132 Were depositors to diversify, one consequence might be a more even distribution of deposit funds among banks. Since large depositors will require a large number of insured banks to receive their diversified deposits, it may happen that banks that otherwise would have no access to the business of large commercial depositors will now hold a share of such depositors' funds. The consequence, of course, is that the deposit base of the banks that would exclusively service such customers absent diversification will fall. The large commercial banks, consequently, could be expected to oppose widespread diversification of deposits, given that a large deposit base affords the bank stability and pleases bank regulators. See M. Stigum \& R. Branch, Managing Bank Assets and Liabilities: Strategies por Risk Control and Profit 91-92 (1983).

1ss Perhaps because of the costs imposed by diversification, depositors who have undertaken it in the present market have sought a higher return on their money, channelling it through deposit brokers to banks in need of funds, unable to borrow on the federal funds 
services and goodwill that a bank often extends to its large depositors. ${ }^{134}$ Since a broad setoff rule reduces the cost of banking for depositors with accounts greater than $\$ 100,000$, while other depositors, because their deposits are fully insured, are indifferent to the choice of setoff rule, depositors ex ante should prefer a broad rule allowing setoffs.

Additionally, the concentration of a customer's loans and deposits in a single institution helps to enhance the going-concern value of the bank. ${ }^{135} \mathrm{~A}$ bank's ability to serve all of a given customer's needs undoubtedly fosters goodwill toward the bank, increasing the likelihood that customers will return with future business and providing a receptive market for new bank services. The relative stability of a bank's customer base can thus reduce mar-

market, and accordingly willing to pay a higher rate of return on brokered deposits. The FDIC recently acted to curtail deposit brokerage, noting that "although brokered deposits at the present time comprise a modest percentage of total domestic deposits, a significantly greater proportion of poorly-rated insitutions use brokered deposits than highly-rated institutions." Brokered Deposits, Limitations on Deposit Insurance, 49 Fed. Reg. 13,003, 13,006 (1984) (amendment to 12 C.F.R. pt. 330). The FDIC further expressed its view that:

insured deposit brokerage is inconsistent with the fundamental and overriding purposes which were meant to be served by the federal deposit insurance system. Deposit insurance was originally intended to establish stability and to promote confidence in the monetary and banking systems by protecting primarily small, relatively unsophisticated depositors in their relationship with banks .... It was not intended to protect investors seeking the highest yields available in money markets.

Id. at 13,005 . In light of this statement, there is room to speculate whether the FDIC would tolerate a widespread practice of diversifying deposits.

As suggested in text, even a fully insured depositor, as a practical matter, is likely to keep track of the financial soundness of the institutions where his funds are deposited. He will not, however, so closely evaluate the soundness of a given institution as in the case where he holds uninsured deposits therein. Consequently, deposit diversification may have the same consequence that the FDIC perceived in the practice of deposit brokerage when it proposed the amendment to 12 C.F.R. pt. 330: "the ability to obtain de facto one-hundred percent insurance through the parcelling of funds eliminates the need for the depositor to analyze one institution's likelihood of continued financial viability" and thereby reduces market discipline. Brokered Deposits, Limitations on Deposit Insurance, 49 Fed. Reg. 2787, 2787 (1984) (proposed Jan. 23, 1984).

134 See J. Culbertson, supra note 79, at 143-44; M. Stigum \& R. BRANCh, supra note 132, at 89-90. To the extent, of course, that a depositor receives such services in return for foregone interest on large demand deposits, he is paying a price for them. That price, however, may well be lower than the price he would otherwise have to pay for such services. For example, a bank that requires a compensating balance in order to extend a line of credit, see supra note 129 and accompanying text, may be willing for a good customer to count the balance maintained in compensation for services toward the compensating balance on the line of credit. See M. Stigum \& R. BRanch, supra note 132, at 90.

${ }^{2 s 3}$ Part of the FDIC's motivation for handling a bank failure by purchase and assumption is a wish not to sever the relationship between loans and deposits. The preservation of that relationship is a way of protecting the "going business" value of the bank. Barnett, supra note 40, at 161 . This element of a failed bank's value justifies the premium paid by the acquiring bank in a purchase and assumption. See supra note 82. 
keting costs and facilitate planning. To the extent that the availability of setoff encourages such concentration, increasing the bank's value and its opportunities for growth, the remedy further reduces the overall cost of banking to the indirect benefit of depositors.

Quite apart from the effect of a broad setoff rule on the present cost of banking, it seems reasonable to speculate that an uninsured depositor contemplating the position he might occupy at the time the bank fails would opt ex ante for a broad rule. If he has already dealt twice with the bank and expects to remain so situated, he will want to be able to exercise his setoff right. If he has not yet dealt twice with the bank, he may anticipate finding himself so situated. For such a depositor, the increased recovery deriving from setoff, discounted by the chance that he will have a setoff claim at the time of the bank's insolvancy, may well be large enough to outweigh the loss he will suffer in the event that he is not in a position to claim a setoff. In other words, even the uninsured depositor who has not dealt twice may prefer to risk subsidizing the enhanced recovery of the depositor who has, rather than to risk finding himself in the position of subsidizing the recovery of the general depositors.

Depositors, however, are not the only creditors of an insolvent bank. Once nondepositor creditors are taken into account it may not be the case that all claimants entitled to pro rata dividends from the liquidation proceeds under section 194 of the NBA $^{136}$ would agree ex ante to a broad depositor setoff rule. Indeed, it could be argued that nondepositor creditors would most certainly disfavor a broad setoff rule insofar as it might constitute a preference, decreasing the amount available for distribution in a ratable recovery. ${ }^{137}$ Moreover, the FDIC's interest in a broad setoff rule as

${ }^{136}$ See 12 U.S.C. $\& 194$ (1982), discussed supra notes 48-49 and accompanying text.

${ }^{137}$ For an explanation of how setoffs can decrease the amount available for distribution in a ratable recovery, see supra text following note 123.

At first glance, the responses of the various bank-participants in Penn Square originated loans to the FDIC's plan to permit depositor setoff, see supra note 17 and accompanying text; infra notes 146-54 and accompanying text, appear to illustrate dramatically such creditor opposition. It should be noted, however, that prior to the allowed setoffs, the participants were effectively investors in the fortunes of the borrowers, with Penn Square assuming a contractual obligation to administer and manage that investment. Indeed, under the terms of the participation agreements, Penn Square made no representation and had no responsibility to the participants "as to the validity of collectibility of the loan . . . " Certificate of Participation No. 3156 Between Penn Square Bank, N.A. and Chase Manhattan Bank, N.A. (July 24, 1981) (attached as Exhibit A to Chase Manhattan Brief, supra note 11). Only after the FDIC as receiver appropriated to Penn Square a share of the given participant's interest in the borrower's obligation in order to satisfy the borrower's deposit de- 
a way of promoting purchase and assumption agreements and of preserving the insurance fund ${ }^{138}$ may not be sufficient reason alone to prefer the interests of depositors over those of nondepositor creditors. ${ }^{139}$

This is a forceful argument against a broad depositor setoff rule-one that highlights not only the anomaly of allowing setoff at all as a bankruptcy remedy, ${ }^{140}$ but also the tension between bankruptcy law principles, which any insolvency brings into play at least implicitly, and the bank regulatory scheme for assuring the safety and soundness of the banking system. ${ }^{141}$ Looking to the special circumstances of a bank failure, one may justify an analysis focusing on the interests of depositors by noting that by far the largest share of claimants against the assets of a failed institution

mand did the participant obtain a claim against Penn Square. By this analysis, the participant might be called a second-tier creditor of Penn Square insofar as its claim against the lead bank hinges upon the obligation of the depositor-borrower, a first-tier claimant. Because the character of the underlying transaction thus puts the participant's interest behind that of the depositor, it seems peculiar to argue that the setoff prefers the depositor over the participant. The setoff is preferential only as to those nondepositor creditors who, like the depositor, have what are here called first-tier claims. Such first-tier nondepositor creditors will generally constitute a small group. See infra note 142 and accompanying text.

138 For a discussion of the FDIC's interest in dealing with bank failures by way of a purchase and assumption agreement, see supra notes 82-107 and accompanying text.

1s9 The Ninth Circuit, in First Empire Bank y. FDIC, 572 F.2d 1361 (9th Cir.), cert. denied, 439 U.S. 919 (1978), concluded that Congress did not intend that the fiscal integrity of the deposit insurance fund should outweigh the policy of the equitable and ratable payment of creditors. The FDIC may not, the Court stated, "whenever it felt its action to be reasonable and to serve to protect the deposit insurance fund against loss . . . prefer some creditors over others-paying some in full while others received little to nothing." Id. at 1371. For further discussion of this case, see supra note 113.

140 See supra notes 30-32 and accompanying text.

${ }^{14}$ See supra notes $25-45$ and accompanying text. This tension became evident in the wake of the failure of the Franklin National Bank in 1974. A number of creditors brought suit urging that the actions of the various bank regulatory agencies in merging Franklin into another bank benefited some creditors of the failed institutions more than others. See In re Franklin National Bank Securities Litigation, 478 F. Supp. 210, 219 (E.D.N.Y. 1979). The court rejected the claim, observing that if such discrepancies did exist, they were

only the result of the unavoidable conflict between the interests of a regulated bank-and its stockholders and creditors-and the broader public interest as viewed by the responsible government officials. The bank regulatory agencies, of course, are charged with protecting the public interest, and here all the actions of the agencies were arguably designed to preserve the stability of the banking system, to minimize the losses to the public, and to reduce the possibility of grave national and international financial repercussions.

Id. at 219; see also Huntington Towers, Ltd. v. Franklin National Bank, 559 F.2d 863, 868 (2d Cir. 1977) (holding that the Federal Reserve Bank's grant of rescue funds to a bank in danger of insolvency was within bank's competence and authority and was the sort of action specifically contemplated by Congress in creating the Federal Reserve System). But see First Empire Bank v. FDIC, 572 F.2d 1361, 1370 (9th Cir.), cert. denied, 439 U.S. 919 (1978), discussed supra notes 113, 139. 
in fact will be depositors, ${ }^{142}$ particularly since the Federal Deposit Insurance Act defines the term broadly for purposes of determining insurance coverage. ${ }^{143}$ As a consequence, the claims of nondepositor, unsecured creditors are likely to constitute a small subclass of those relegated to a ratable recovery of their claims. ${ }^{144}$ Moreover, the bank regulatory scheme reflects an overall policy to protect particularly the interests of depositors. ${ }^{145}$

The lingering problem posed by the existence of nondepositor creditors remains, to be sure, a troublesome one. But given the dominance of depositors among a bank's general creditors, in conjunction with the regulatory policy to guard their interests, there seems little reason to reject a broad depositor setoff rule because it is not consistent with a perfectly collective, nonpreferential resolution of claims against the insolvent bank. Indeed, insofar as current bankruptcy law tolerates setoffs and the preferences they create, it seems inconsistent to disallow them to depositors of a failed bank on account of the interests of a small group of nondepositor creditors.

\section{Setoff and the Penn Square Failure}

In Chase Manhattan Bank v. FDIC, ${ }^{146}$ the first Penn Square setoff case, ${ }^{147}$ the court addressed the question of whether a depositor who has borrowed from a failed bank may set off his deposit balance against his loan obligation when the bank has sold a participation interest in the loan to another institution. ${ }^{148}$ On July 19,

${ }^{142}$ Large money center banks, which participate heavily in the money market, will have more nondepositor creditors than smaller banks. See M. STigum \& R. BraNch, supra note 132, at 106-07. Not all money market dealings, however, give rise to unsecured nondeposit obligations. Of the four major money market transactions-purchases of federal funds, purchases of Eurodollars, certificates of deposit and repurchase agreements-only the first two give rise to nondepositor creditor claims, since repurchase agreements are secured transactions and certificates of deposit are simply large denomination deposits. See id. at 94-100. Moreover, at the time a bank fails, claims arising from participation in the federal funds and Eurodollar markets may well be small since a bank's access to such funds will shrink markedly as word of its financial straits leaks out. See id. at 95.

143 See 12 U.S.C. § 1813(1) (1982).

144 Secured creditors of a failed bank are entitled to the priority their property interest in collateral affords. See Ticonic National Bank v. Sprague, 303 U.S. 406, 412-13 (1938).

145 The best evidence of this concern with the interests of depositors is the central position of the FDIC in the bank regulatory scheme.

146554 F. Supp. 251 (W.D. Okla. 1983).

147 While commentators contemplated many suits after Penn Square, see, e.g., Skillern $\&$ Topelius, supra note 94 , at 20 , and at least one other suit was filed, see supra note 17 , the result in Chase Manhattan probably rendered these other contemplated suits moot.

148 For a discussion of how this question arose in the context of the Penn Square failure, see supra notes 7-17 and accompanying text. 
1982, less than two weeks after the Comptroller of the Currency closed the Oklahoma City bank, Chase, which held approximately $\$ 212$ million in Penn Square participations, ${ }^{149}$ brought suit seeking a temporary restraining order and ultimately a permanent injunction to prevent the FDIC from allowing Penn Square customers to set off their deposit balances against participated loans. ${ }^{150}$ After an intricate exchange of motions, ${ }^{151}$ the court granted the FDIC's alternative motion to dismiss, ${ }^{152}$ and held that Chase had no basis in law to claim rights in the amounts offset superior to those of the depositors. ${ }^{163}$

A simplified hypothetical case illustrates Chase's reason for bringing suit to enjoin setoff. Imagine a depositor $D$ in a troubled Bank $A$ who, at the time of the bank's failure, has a deposit balance of $\$ 150,000$ and an outstanding loan obligation of $\$ 200,000$. Imagine as well that Bank $A$ has sold a $75 \%$ participation interest in the loan to Bank $B$. Assuming that the FDIC is unable to arrange a purchase and assumption transaction and must pay off depositors up to the insured limit, both $D$ and the FDIC will benefit from the setoff. Since his loan obligation exceeds his deposit, $D$ recovers his deposit in full by offsetting $\$ 150,000$ of his loan obligation against his $\$ 150,000$ deposit. At the same time the FDIC's obligation to $D$ has fallen from $\$ 100,000$ to nothing. ${ }^{154}$ Bank $B$, however, is disadvantaged by the offset. As a $75 \%$ participant in the loan it had expected to receive $\$ 150,000$. After the setoff, however, $D$ remains obligated to pay only $\$ 50,000$ of the loan, $75 \%$ of which is $\$ 37,500$. Unless Bank $B$ can argue successfully that the setoff is wrongful, it stands to lose a substantial portion of its investment.

In Chase Manhattan Bank v. FDIC, the court rejected the claim that the setoff was wrongful, citing Scott $v$. Armstrong ${ }^{\mathrm{IS5}}$ and FDIC v. Mademoiselle of California, ${ }^{156}$ a 1967 case holding that "the unannounced transfer of an interest or sale of a participation certificate in the note should not dilute the uninformed depositor's

169 Chase Manhattan Brief, supra note 11, at 3.

${ }^{150}$ Chase Manhattan, 554 F. Supp. at 253.

151 For a complete procedural history of this case prior to its dismissal in early January, 1983, see id. at 252-53.

152 Id. at 257.

2ss Id.

154 The FDIC insured limit is $\$ 100,000$. See supra note 52 and accompanying text. Since $D$ has credited his entire deposit against his loan, the FDIC is not obligated to pay $D$ anything as return on his deposit.

158146 U.S 499 (1892), cited in Chase Manhattan, 554 F. Supp. at 254. The Scott case is discussed at length, supra notes 55-75 and accompanying text.

1s6 379 F.2d 660 (9th Cir. 1967), cited in Chase Manhattan, 554 F. Supp. at 254. 
ordinary right of set-off."157 The Mademoiselle holding, though framed in terms of equity to the unsuspecting depositor, is consistent with the view proposed in this comment that setoff is a mechanism for relieving a depositor who has dealt twice with the bank from the burden of subsidizing the collective recovery. ${ }^{158}$ So defined, the setoff right arises from the depositor's dealings with the lending bank and his implicit bargain with other depositors. The bank should not be able to trade upon that right in a subsequent unilateral transaction with third parties involving the depositor's accounts. If a lending bank were able to curtail a depositor's setoff right by selling a participation interest in the loan, it would have the power to adjust unilaterally the allocation of risks and rights in insolvency for which the depositor presumably bargained, ${ }^{159}$ and which is to the benefit of both depositors generally ${ }^{\mathbf{1 6 0}}$ and the regulatory system governing bank insolvencies. ${ }^{161}$ Unless the depositor has specifically agreed that the sale of a participation interest will extinguish his setoff right, the lending bank should not be able to convey to the participating bank a power to enjoin setoff. ${ }^{162}$

In response to the emphasis in Mademoiselle on the depositor's knowledge of the participation, ${ }^{163}$ Chase argued that a number of the depositors seeking offset were aware that their loans depended on Penn Square's ability to sell a participation in the loan to another bank. ${ }^{164}$ Virtually all the depositors, Chase claimed, at

${ }^{157} 379$ F.2d at 664 . In Mademoiselle, the FDIC sought to prevent the claimed setoff, presumably on the ground that to permit the remedy would impose a burden on the general depositors and, because of its right of subrogation, on the FDIC. It is possible that the FDIC sought to prevent the extension of the setoff right to circumstances involving a participation interest. Cf. Barnett, supra note 40, at 163 (stating that the FDIC would prefer in a purchase and assumption to exclude contingent liabilities, which also has the result of favoring general depositors). In Chase, however, the FDIC took the opposite position. This shift of position may merely reflect the FDIC's acquiescence in the Mademoiselle holding, but it may also reflect its recognition that within its overall regulatory scheme a broad setoff rule is preferable to a narrow one. See supra notes 95-116 and accompanying text.

${ }^{183}$ See supra notes $123-30$ and accompanying text.

159 See supra notes 117-30 and accompanying text.

160 See supra notes 131-34 and accompanying text.

161 See supra notes 76-116 and accompanying text.

${ }_{162}$ One might allow setoff to the extent of the unparticipated amount of the loan. See Hutchins, supra note 10 , at $466 \&$ n.158. This approach is no better than denying setoff altogether since it fails to take cognizance of the fact that the borrower's obligations arose from its dealings with the lead bank. The subsequent transaction between the lead bank and the participant does not implicate the borrower.

16s See supra text at note 157.

${ }^{164}$ Affidavit of Edward G. Moran (a vice president of Chase Manhattan), in Chase Manhattan Brief, supra note 11, at 2. A lead bank will often arrange a participation in circumstances where it could not make the loan itself without exceeding its lending limit. See Tompsett, Interbank Relations in Loan Participation Agreements: From Structure to 
least knew that a participation interest in their loans had been sold. ${ }^{165}$ In light of such knowledge and given that a number of the depositor-borrowers were Penn Square insiders, ${ }^{166}$ Chase argued that the setoff was not justified. ${ }^{167}$

This argument has some merit. Those borrowers who knew that their loans were made possible by the participation of other banks certainly are not among the "uninformed depositors" that the Mademoiselle court sought to protect. One might argue that to allow such borrowers to set off is to allow them to avoid the implicit bargain they made with the participant banks. This argument, however, ignores the fact that the setoff remedy arises from a depositor's symmetrical relationship with the lead bank as depositor-borrower; it does not encompass subsequent transactions between the lead bank and other institutions. In the absence of separate agreements or a negotiated waiver of setoff rights, the participant should not be able to interfere with the bargain struck between the lead bank and the depositor-borrower. While this result may seem inequitable and expensive in the present case, given the fact that a number of the borrowers were Penn Square insiders, it nevertheless seems best to uphold a rule that preserves the integrity of the setoff remedy along with the allocation of rights and risks it embodies, and to place the burden of modifying that rule on the participant bank. Chase can protect itself from loss by contracting around the setoff rule before purchasing a participation interest. ${ }^{168}$ If a participant could curtail setoff rights without such an agreement, the uninformed depositor would be unable to protect himself in the case where the lead bank unilaterally sold a participation in his loan. ${ }^{189}$ Chase may be able to recover from the

Workout, 101 BANkING L.J. 31, 32 (1984).

1es Affidavit of Edward G. Moran, in Chase Manhattan Brief, supra note 11, at 2.

${ }^{168}$ Id. at 3; see Chase Manhattan Brief, supra note 11, at 4.

${ }^{187}$ Chase Manhattan Brief, supra note 11, at 26-27.

${ }^{168}$ See supra note 12 and accompanying text. Armstrong notes that such side contracts are not properly included in a participation agreement but are totally separate contracts. Armstrong, supra note 10, at 693-94; see also Essay, supra note 4, at 272 (proposing that loan participants should contract against the borrower's right of setoff).

${ }^{168}$ In the face of a rule allowing participants to enjoin setoff by the depositor-borrower, the latter could contract with the lead bank at the time the loan is made to the effect that if a participation interest in the loan is sold, then the lead bank shall limit by contract the participant's power to enjoin setoff. But insofar as the participation is a transaction serving the interests of the lead bank and the participants, it seems improper to impose the initial burden of negotiating a rule change upon the depositor-borrower. The balance of equities may shift from the depositor-borrower somewhat in the case where the lead's ability to lend to him depends upon its ability to arrange a participation. See supra note 164 and accompanying text. In such a case, however, the burden on the participant of negotiating a rule 
Penn Square insiders on other grounds, such as fraud, but it should not be able to do so by curtailing a remedy that does not arise from its dealings with either the depositor-borrower or Penn Square.

As a result of the Chase Manhattan court's reasoning, ${ }^{170}$ Chase, like the holder of an uninsured deposit, must recover pro rata from the proceeds of the Penn Square liquidation. ${ }^{171}$ While this result, as this comment demonstrates, is correct, the financial loss to Chase and participants in Penn-Square-originated loans is substantial. Such losses may be avoided in the future if participating banks negotiate not only with the lead bank but also with the depositor-borrower whose right of setoff otherwise takes priority over the participant's interest in the loan.

\section{ConcLusion}

Since the 1892 decision of the Supreme Court in Scott v. Armstrong, there has been a presumption that a depositor in a failed bank may set off his deposit against any obligation he may owe to the institution. The failure of forty-two FDIC-insured banks in 1982, including the Penn Square Bank of Oklahoma City, and of forty-eight in 1983, has re-opened questions about the scope of the setoff right and its rationale. This comment argues that the broad setoff rule announced in $S$ cott, though poorly justified by the Court, is the proper rule. Under the law governing the FDIC, the

change is considerably lighter. A depositor otherwise unlikely to forego his setoff right, see Tompsett, supra note 164 , at 46 , will be much more willing to do so if he knows that his ability to borrow depends upon it.

${ }^{170}$ In the order granting the FDIC's motion to dismiss, the court noted in conclusory fashion that setoff was available to the depositor-borrowers under the rule of Scott v. Armstrong. Chase Manhattan, 554 F. Supp. at 254; see supra notes 74-75 and accompanying text. The court devoted the largest part of its attention to a further argument put forth by Chase-that it held a preferred claim to its share of the amounts offset. While the court passed quickly over the question of whether or not the setoff was wrongful, see Memorandum Order of July 19, 1982, Denying Chase Manhattan's Motion for a Temporary Restraining Order at 2, Chase Manhattan Bank v. FDIC, 554 F. Supp. 251 (W.D. Okla. 1983), the matter remained an issue in the FDIC's reading of Chase's amended complaint. See FDIC Reply Brief, supra note 17, at 4. See also Northern Trust Amicus Brief, supra note 17, at 3-4 (arguing that the question of the propriety of offset was fact-based and could not be summarily decided). Chase's alternative argument, which goes to the nature of the contract between Penn Square and Chase, is beyond the scope of this comment. It is enough to note the court's holding that nothing in the bargain struck between Chase and Penn Square gave the former a property interest in the deposit balances offset. Chase Manhattan, 554 F. Supp. at 256. Chase therefore had no preferred claim and no alternative but to accept a receiver's certificate for its share of the loan extinguished by the allowed setoffs. Id. at 25657.

${ }^{171}$ Chase Manhattan, 554 F. Supp. at 253. 
broad availability of the right makes it easier for the agency to merge a failed bank into a solvent institution, thereby minimizing the disruptive effects of a bank liquidation. More importantly, setoff protects the depositor from an asymmetrical resolution of his claims against the insolvent bank, and reduces the cost of banking for both banks and depositors. The comment turns finally to an examination of a complicated setoff dispute arising in the aftermath of the Penn Square failure, and concludes that in the absence of a specific contractual provision to the contrary between the depositor and the participant, the former's setoff right should prevail over the participation interest.

Willis R. Buck Jr. 